\title{
United Kingdom: Film Funding, the "Corporate Welfare System” and Its Discontents
}

\author{
AQ1 \\ Jack Newsinger $1 \bowtie$ \\ Email Jack.newsinger@nottingham.ac.uk
}

\section{Jack Newsinger}

is an aAssistant ${ }_{p}$ Professor in eCultural industries at the University of Nottingham. His work focusses upon policy and labour in the cultural and creative industries. His research has been funded by the British Academy, the Arts and Humanities Research Council and the British Film Institute. He is a convener of the Screen Industries Special Interest Group of the British Association of Film, Television and Screen Studies, an associate researcher of the Cultural and Media Economies (CAMEo) Research Institute and a member of the Radical Film Network.

Steve Presence 2

Email Stephen2.presence@uwe.ac.uk

\section{Steve Presence}

is a Senior $¥$ Research fFellow in film and television at the University of the West of England (UWE Bristol). His research interests include political film culture, documentary and the British film and television industries. He is currently the pPrincipal investigator on the Arts and Humanities Research Council project, "Sustaining Alternative Film Cultures" (2015-2017) and eCo-iInvestigator on "Bristol Film \& TV Industries (BFTV)", an industry mapping project funded by the Higher Education Innovation Fund. He is also cofounder of the Bristol Radical Film Festival, convener of the Radical Film Network and associate editor of the peer-reviewed journal for screen-based practice research, Screenworks.

University of Nottingham, Nottingham, UK

2 University of the West of England (UWE) Bristol, Bristol, UK

\section{Abstract}

The abstract is published online only. If you did not include a short abstract for the online version when you submitted the manuscript, the first paragraph or the first 10 lines of the chapter will be displayed here. If possible, please provide us with an informative abstract.

This chapter maps public funding for film in the UK and explores some of the contradictions between stated policy aims and outcomes, particularly on the issue of "creative labour". Via the now wellestablished and relatively substantial public funding systems for film production that exist in the UK, considerable public funds are directed towards transnational corporate interests and their national partners, a policy approach that we call "a corporate welfare system" for the UK film industry. This system has had considerable success on its own terms, leveraging massive investment into UK film infrastructure, and has provided a blueprint for the economic development of other creative industries. However, it has also hindered wider policy commitments towards diversity and equality in the film workforce. It is argued that policy objectives to improve opportunities for underrepresented groups such as women, ethnic minorities, disabled people and people of working class origin are unlikely to be successful unless more direct interventions can be developed.

\section{Keywords}

"Cultural test" 
Corporate welfare system

Creative industries

Creative labour

Diversity

Inequality

New Labour

Social justice and equality

Production companies

Tax relief

UK film policy

\section{The British Film Industry: Tax Relief and the Problem of Equality}

The use of tax relief to attract inward investment has comprised the foundation of the UK film industry since its introduction in 1992. Although the amounts and mechanisms of film tax relief have changed considerably since then, the fundamental principle of offering massively reduced tax incentives to film producers remains, and it has transformed the industry. The UK is now one of the most competitive places in the world to produce feature films, and the industry is larger, makes more films, employs more people and generates more money as a result (Olsberg SPI, 2015). Indeed, tax relief for film has proved so successful that a suite of similar tax reliefs have been introduced across the creative industries: for animation (2013), high-end television drama (2013), video games (2014), theatre (2014), children's television (2015) and orchestras (2016). Yet for all the benefits that tax relief affords the film industry in the UK, its primary beneficiaries are the Hollywood studios and other major multinational media corporations. The vast majority of the inward investment attracted by the tax relief system comes from Hollywood, and while this has helped boost employment and developed the UK's state-of-the-art facilities and world-leading talent and crews, the cost has been - and continues to be - a publicly funded "corporate welfare system" worth hundreds of millions of pounds to the British taxpayer, and a British film industry chiefly engaged in the production of Hollywood cinema.

Arguments about the advantages and disadvantages of the UK film tax relief scheme are well rehearsed, as we will show. However, our objective here is to explore a perspective that is much less discussed and make an argument about the relationship between this mode of film funding and what we see as its damaging implications for social justice and equality in terms of citizens' opportunity to participate in the film industry and film culture, what is called "diversity" in contemporary public discourse in the UK. First, we explore the concept of corporate welfare and the emergence of commercial subsidy as a cornerstone of creative industries policy in the UK. We then investigate how the corporate welfare system for film funding contributes to the stratification of the UK production sector. Finally, we analyse the relationship between this system of funding and production and the dismal levels of diversity in the industry workforce. We explore the multiplicity of ways in which often indirect, unconscious and intersecting prejudices construct barriers that prevent equal participation for women, ethnic minorities, disabled people and working class people, particularly to higherstatus creative roles, and how these barriers are structured into the largely freelance and informal labour markets and labour processes upon which the success of the UK film industry is built. It is our central argument that the current form of UK film funding maintains a structure and organisation of the film industry that directly opposes one of the stated key priorities of UK cultural policy: to "promote a more diverse workforce" (DCMS, 2008, p. 23).

\section{The "Corporate Welfare System" and the Depoliticisation of Commercial Subsidy}

The concept of the "corporate welfare system" features heavily in US debates on social and economic policy and is generally a pejorative term referring to the practice of large corporations lobbying for, and receiving, government subsidies (see Huff \& Johnson, 1993; Nader, 2000). In contrast, in the UK, following the "markets work best" doctrine of the 1980s, mainstream political consensus has held that subsidy of commercial interests is a legitimate use of public money if it generates positive "externalities" such as the creation of jobs or the provision of services (Whitfield, 2001). 
Debates on the subsidisation of commercial media and culture have a complex history that is bound up with the development of the "cultural industries" approach to cultural policy in the 1980s and the subsequent adoption of the "creative industries" as a policy paradigm and official sector of the economy in the late 1990s (Flew, 2012; Garnham, 2005; Hesmondhalgh \& Pratt, 2005; Hesmondhalgh, Oakley, Lee, \& Nisbett, 2015b; Newsinger, 2012b; Schlesinger, 2007). Hesmondhalgh et al. (2015a, b) argue that New Labour's cultural policy was the result of a complex series of tensions between various institutional, political and social forces, particularly social democratic policies aimed at redistributing cultural resources, contributing to social justice and mitigating market failure, and others, perhaps best described as "neoliberal" in character, which were designed to strengthen commercial activity and market operations. In this way, the corporate welfare system for film might be understood as a representation of these tensions, containing at once a cultural concern for the construction of an indigenous film culture, a social concern for the creation of employment and opportunity and a more neoliberal concern that sees market operations, competition and commercial success as the best mechanisms for economic growth and the allocation of resources.

However, while New Labour's social and cultural programmes were a significant - although secondary - part of the creative industries discourse, these concerns were ultimately subordinated to commercial interests. As Hesmondhalgh et al. (2015b) argue, film policy in this period demonstrates "a privileging of the interests of the cultural industries", "less concern with cultural factors" and a "neglect of problematic working conditions in the sector" (p. 122). Despite the continued vestigial attachment to social and cultural policy aims and objectives, the dynamism of the creative industries discourse played a central role in delegitimising nonmarket forms of cultural subsidy and depoliticising commercial subsidy. Thus, while public funding increased during the New Labour period, this was part of a process of the stripping back of social democratic values and practices, transferring cultural authority and material power ever increasingly to commercial markets and corporate interests. This interpretation helps to explain the continuation and extension of creative industries policy and practice after New Labour and its seamless continuity with a renewed Conservatism and financial austerity (for a more detailed version of this argument, see Newsinger, 2012a, 2014).

From a technocratic public policy perspective, an evaluation of the corporate welfare system for film might be posed as a question of balancing positive externalities with negative ones. However, as noted by a number of critics, in the development of creative industries policy, questions about the pay and conditions for labour rarely made it into the equation, being sidelined or ignored under the presumption that increased commercial activity was an unmitigated public good (e.g. Banks \& Hesmondhalgh, 2009; Oakley, 2013).

We want to suggest that the role of corporate welfare system in limiting democratic accountability and maintaining systemic barriers to equal participation needs to be factored into this equation as a negative consequence with much more weight than has previously been the case.

\section{Film Funding in the UK}

Tax relief is the cause of most economic activity associated with feature film production in the UK. Of the $£ 1.4$ billion ( 1.7 billion euros) spent in 2015 , for example, the vast majority $-83 \%$, or $£ 1.2$ billion (1.4 billion euros) - came from overseas, predominantly for Hollywood films made in the UK, such as Rogue One: A Star Wars Story and Pirates of the Caribbean: Dead Men Tell No Tales AQ2

(BFI, 2016a, p. 3) (Fig. 1).

\section{Fig. 1}

UK spend of feature films produced in the UK, 1994-2015, £ million (BFI, 2016a, p. 3) 


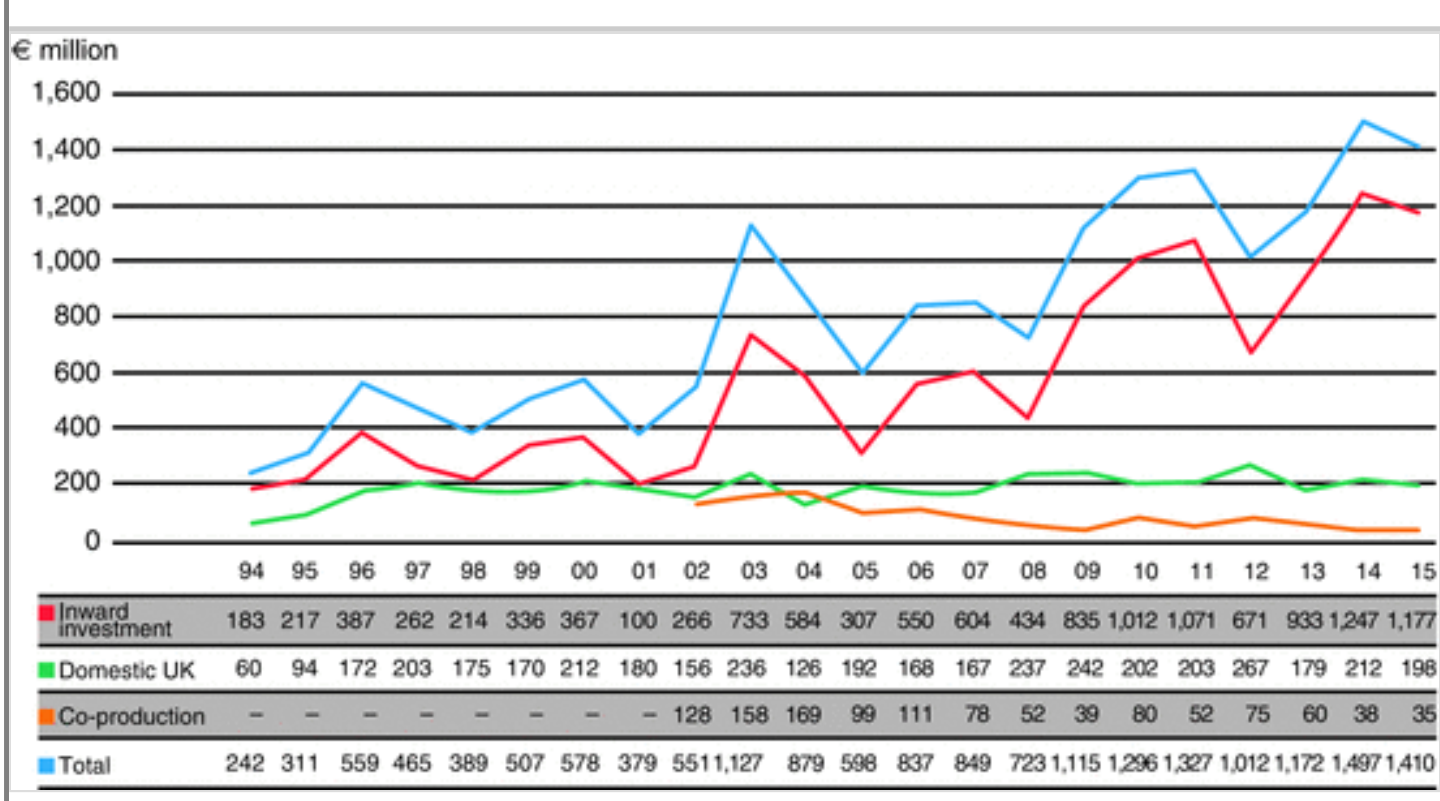

By contrast, the total public funding for film production was a comparatively miniscule $£ 414$ million (481 million euros), of which more than half $(61 \%)$ was automatically allocated to those films that qualify for the film tax relief. Of the rest, most comes from the National Lottery (18\%, in 2015), a state sweepstake scheme set-up in 1995, central government $(8 \%$, in 2015) and the film production arms of the two main public service broadcasters (PSBs), the BBC (British Broadcasting Corporation)/BBC Films and Channel 4/Film $4(6 \%$, in 2015) (BFI, 2016b, p. 3). The remainder consists of various investments of $<2 \%$ from public bodies such as the Arts Council, the EU's MEDIA programme and various national and regional government departments across the UK (BFI, 2016b, p. 4). In economic terms, then, the UK film industry makes mostly Hollywood films that are attracted to the UK by its competitive, taxpayer-funded corporate welfare system.

That tax relief which is by far the single largest source of public funding for film in the UK is indicative of the extent to which the film industry is valued in primarily commercial terms by the state. Rather than using public funds to mitigate market failure, tax relief transfers those funds to the private sector and thereby boosts the commercial operation of the industry by reducing the costs and risks involved in private investment. Of course, the tax relief was ostensibly designed to benefit indigenous producers, and, to the extent that all films which qualify can claim back $25 \%$ of the first $£ 20$ million ( 24 million euros) spent and $20 \%$ of any subsequent spend, it does. However, because tax relief is proportionate to production spend, levels of subsidy for big-budget films far exceed anything available to indigenous filmmakers because the latter make films with considerably smaller budgets. Furthermore, the tax relief scheme has been so successful at attracting runaway productions to the UK that many of the high-end crews and facilities are contracted out by bigbudget productions for much of the year and thus unavailable to independent producers. So, although the tax relief keeps production levels high, which in turn maintains the skills base and keeps people in work, those that ultimately benefit most from such stimulus are those organisations best placed to benefit from the commercial side of the industry. Although this includes the handful of British production companies that work with Hollywood finance (see below), the principal beneficiaries are the investors themselves:

Hollywood studios and other major multinational media corporations based overseas (Presence, 2017; Steele, 2015).

Tax relief was first introduced in 1992 as part of a raft of other measures designed to counter the effects of a more extreme free-market approach to the film industry. In 1984, Margaret Thatcher's Conservative administration removed all forms of government support for the industry - which she referred to as the "paraphernalia of government intervention" - and brought the industry to the brink of collapse: investment in production fell from $£ 270.1$ million (320.1 million euros) in 1986 to $£ 49.6$ million (55.6 million euros) in 1989, in which just 30 films were made (Hill, 1996, pp. 103-104). As well as tax relief, other interventions included the establishment of the British Film Commission to attract inward investment in 1991; in 1993 the UK joined Eurimages, the European fund for production, distribution and exhibition; and in 1995 National Lottery funding for film was introduced, and the London Film Commission was established to attract inward investment to the capital (Caterer, 2011). Aside from the UK's membership of Eurimages (which was 
withdrawn in 1996), ${ }^{3}$ the essence of these policies remains in place today despite significant changes to the institutional infrastructures that oversee and administer them (Doyle et al., 2015). As such, the policy shift of the 1990s marks the beginning of the current epoch of film policy in which the economic foundation of the industry is based upon attracting inward investment via tax relief, while comparatively miniscule levels of funding from the Lottery and PSBs support low- to medium-budget, "culturally British" film.

AQ4

AQ5

\section{Film Production in the UK}

Under the current rules, introduced in 2007 and revised in 2014, to benefit from the relief, films must both be produced by a British production company and either pass a "cultural test" as a British film or be registered as an official UK co-production. ${ }^{4}$ The UK currently has bilateral co-production agreements with 12 other countries, while the cultural test is a points-based system that allocates points based on content, language, above- and below-the-line labour and so on (Table 1). This would appear to ensure that only culturally British films, or British co-productions made by British companies, can benefit from the relief.

\section{Table 1}

Summary of points, cultural test for film

\section{Cultural test}

Points

\section{A Cultural content}

A1 Film set in the UK or EEA

A2 Lead character British or EEA citizens or residents points

A3 Film based on British or EEA subject matter or underlying material

A4 Original dialogue recorded mainly in English or UK indigenous language or EEA language

Total Section A

\section{B Cultural contribution}

The film demonstrates British creativity, British heritage and/or diversity

Total Section B

C Cultural hubs

C1 (a) At least $50 \%$ of the principal photography or SFX takes place in the UK

(b) At least $50 \%$ of the VFX takes place in the UK

(c) An extra 2 points can be awarded if at least $80 \%$ of principal photography or VFX or SFX takes place in the UK 


\begin{tabular}{|c|c|c|}
\hline & Cultural test & Points \\
\hline & Total Section C (maximum 4 points in total in $\mathrm{C} 1$ ) & $\begin{array}{l}5 \\
\text { points }\end{array}$ \\
\hline $\mathrm{D}$ & Cultural practitioners (UK or EEA citizens or residents) & \\
\hline D1 & Director & $\begin{array}{l}1 \\
\text { point }\end{array}$ \\
\hline $\mathrm{D} 2$ & Scriptwriter & $\begin{array}{l}1 \\
\text { point }\end{array}$ \\
\hline D3 & Producer & $\begin{array}{l}1 \\
\text { point }\end{array}$ \\
\hline D4 & Composer & $\begin{array}{l}1 \\
\text { point }\end{array}$ \\
\hline D5 & Lead actors & $\begin{array}{l}1 \\
\text { point }\end{array}$ \\
\hline D6 & Majority of cast & $\begin{array}{l}1 \\
\text { point }\end{array}$ \\
\hline D7 & $\begin{array}{l}\text { Key staff (lead cinematographer, lead production designer, lead costume designer, lead editor, lead } \\
\text { sound designer, lead visual effects supervisor, lead hair and makeup supervisor) }\end{array}$ & $\begin{array}{l}1 \\
\text { point }\end{array}$ \\
\hline D8 & Majority of crew & $\begin{array}{l}1 \\
\text { point }\end{array}$ \\
\hline & Total Section D & $\begin{array}{l}8 \\
\text { points }\end{array}$ \\
\hline & Total all sections (pass mark 18) & $\begin{array}{l}35 \\
\text { points }\end{array}$ \\
\hline \multicolumn{3}{|c|}{ Source: BFI (2017) } \\
\hline \multicolumn{3}{|c|}{$\begin{array}{l}\text { However, because the tax relief is principally designed to attract inward investment, British companies } \\
\text { working with Hollywood finance must be able to qualify. Therefore, the so-called cultural test for British film } \\
\text { is sufficiently weak that Hollywood films made by British companies in the UK, such as Gravity (2013) or } \\
\text { Fast and Furious } 6 \text { (2013), can pass as culturally British and thus benefit from the scheme (Hill, 2016). Thus } \\
\text { Gravity, a film majority financed by Warner Bros. about two American astronauts in space, was eligible for } \\
\text { tax relief as a British film because it was produced by Heydey Films (the London-based company best known } \\
\text { for the Harry Potter franchise) and passed the cultural test because the dialogue was in English and it was } \\
\text { made in Pinewood Studios by crews from Britain and the European Economic Area and because its Mexican } \\
\text { writer and director reside in London. In effect, the rules governing tax relief ensure only that Hollywood } \\
\text { studios support the UK industry indirectly by forcing the studios to work with UK companies. Although this } \\
\text { benefits the UK film industry in several ways, it also has a variety of adverse effects of the production sector. } \\
\text { AQ6 }\end{array}$} \\
\hline \multicolumn{3}{|c|}{$\begin{array}{l}\text { Large but unpredictable levels of inward investment from the USA combined with inadequately low levels of } \\
\text { public subsidy have helped perpetuate a notoriously unstable film production sector that is small and } \\
\text { fragmented, divided across the two opposing sources of support on which it depends. UK film production is } \\
\text { heavily concentrated in London and the south-east and polarised between a large number of small, } \\
\text { independent companies and a small number of bigger companies with established ties to Hollywood. } \\
\text { Unsurprisingly, it is the small number of relatively large companies that makes the bigger-budget films ( } £ 10 \\
\text { million or above; } 12 \text { million euros or above) with Hollywood finance. Although these large-scale productions } \\
\text { represent the bulk of the overall UK production spend, they account for just a small fraction of the total films } \\
\text { produced. In } 2015 \text {, for example, } 201 \text { films were made in the UK, yet just } 15 \text { big-budget (£30 million or } \\
\text { above; } 36 \text { million euros or above) films accounted for } 73 \% \text { of the total production spend (BFI, 2016a, p. 2). }\end{array}$} \\
\hline
\end{tabular}


The proportion of UK spend associated with inward investment films more generally was even higher: $83 \%$. The median budget for these inward investment films was £13.1 million (15.2 million euros); for domestic UK films, the median was only $£ 500,000$ year (581,000 euros) (Table 2).

Table 2

Median feature film budgets, $£$ million, 2009-2015

\begin{tabular}{|l|l|l|l|l|l|l|l|}
\hline Production category & $\mathbf{2 0 0 9}$ & $\mathbf{2 0 1 0}$ & $\mathbf{2 0 1 1}$ & $\mathbf{2 0 1 2}$ & $\mathbf{2 0 1 3}$ & $\mathbf{2 0 1 4}$ & $\mathbf{2 0 1 5}$ \\
\hline Inward investment & 18.45 & 13.09 & 17.64 & 1.58 & 11.24 & 12.61 & 13.10 \\
\hline Domestic UK & 0.20 & 0.13 & 0.17 & 0.15 & 0.15 & 0.26 & 0.5 \\
\hline Co-production & 1.35 & 2.56 & 1.10 & 1.05 & 1.01 & 1.40 & 1.27 \\
\hline
\end{tabular}

Source: BFI (2016a, p. 8)

The handful of UK companies that work with Hollywood finance do of course benefit from the studios' investment. This includes companies such as Working Title, Heydey Films and Scott Free Films. Most of these companies have established ties to Hollywood or other major international media corporations: Working Title is a subsidiary of Universal Pictures; Heydey Films has a first-look deal with Warner Bros., with which it produced all eight films in the Harry Potter franchise; and Scott Free Films, Ridley Scott's company, is run by former Columbia Pictures executive, Michael Costigan, and is part of Scott's wider content creation company, RSA Films, which has offices in LA, Hong Kong and Shanghai. These companies are very successful, but they are not representative of the industry overall. The vast majority of productions companies are small, are independent and struggle from one project to the next, typically making one film per year with the support of one of more of the three main funders: the BFI, BBC Films or Channel 4.

Despite their comparatively paltry resources, these funders support a wide range of independent British films each year. Yet the small sums with which they work are insufficient to address the structural issues faced by the production sector. The BFI's Film Fund has an annual budget of around $£ 26$ million (31 million euros). It finances approximately 25 major feature film awards each year and provides development support for around 100 more, as well as support for distribution and sales. This is the largest annual budget of all the public funders by far, but is still $£ 6$ million (7 million euros) less than the $£ 32$ million ( 38 million euros) budget for Paddington (2014), Heydey Films' Studio Canal-financed film about the famous Peruvian bear, and is positively dwarfed by the $£ 132$ million (156 million euros) spent (even before P+A costs) on Star Wars: The Force Awakens (2015). After the BFI, Film 4 is the next largest: it currently consists of a $£ 15$ million (18 million euros) budget and aims to make between 10 and 12 films per year, while the BBC aims to produce 8 films per year with its budget of $£ 11$ million (13 million euros). Additional four agencies in each country of the UK-Creative England, Film Cymru Wales (Film Agency Wales), Creative Scotland and Northern Ireland Screen-also provide a range of smaller funding and development opportunities relating to their areas, as does Film London, the screen agency for the UK's film-making capital. These agencies are financed with a mixture of government funds and, via the BFI, money from the National Lottery and award production funds between $£ 200,000$ (237,000 euros) and $£ 800,000$ (948,000 euros).

As noted, the low- to medium-budget films supported by these public organisations comprise the majority of features made in the UK each year. ${ }^{5}$ Yet despite their mostly low budgets, because they rely on such poorly resourced public funders, none of these films are single-source financed. Instead, projects financed by the BFI, Film 4 and BBC Films use the backing of the public funder/s to secure further finance from a patchwork of other sources, including the agencies above, presales from distributors and sales agents or contributions from investment banks or private equity firms. With such a large number of stakeholders involved, this patchwork or "jigsaw" financing model is complex, is time-consuming and has to be repeated for each project.

\section{Funding, Production and Workforce Diversity}


The model of film funding that depends on tax relief has had remarkable success on its own terms. Although it fluctuates each year, inward investment has risen steadily from $£ 182.7$ million (216.5 million euros) in 1994 to $£ 356.8$ million (422.9 million euros) in 2008, £752.7 million (892 million euros) in 2009 and $£ 1.18$ billion (2.1 billion euros) in 2015 (BFI, 2016a, p. 3; UKFC, 2010, p. 134). Unsurprisingly, these levels of investment have proved popular with those figures in the industry that benefit from them. Michael Kuhn of Qwerty Films, for example, describes the system as "fantastic" and designed "very cleverly, very effectively" (House of Lords Select Committee on Communications, 2010, p. 27). Similarly, Ivan Dunleavy, chief executive, Pinewood Group plc, describes it as "a clear demonstration of how [the] government has supported UK Film and helped fuel growth in the creative industries to the benefit of the taxpayer" (Quoted in Treasury Press Release, 21st August 2015, n.p.).

The British film industry and the corporate welfare system paradigm that supports it enables films to be made in the UK, utilising UK talent and facilities and sometimes reflecting aspects of UK culture. As pointed out by a number of critics, however, such success - measured primarily in terms of commercial and economic competitiveness - has tended to sideline important questions about inequalities in access to labour markets and poor conditions within them, questions that are only recently entering into mainstream debate (Banks \& Hesmondhalgh, 2009; Comunian, Faggian, \& Jewell, 2011; Oakley, 2011, 2013). While a number of highprofile initiatives by funders and broadcasters have sought to address the lack of diversity in the creative industry workforce (Arts Council England, 2011; Creative Scotland, 2015; Creative industries Federation, 2016), little work has highlighted the role of public funding for film in maintaining the systemic barriers to equality that characterise the industry.

That the industry has a problem with equality and diversity is beyond dispute. For example, according to Creative Skillset's Creative Media Census report, representation of Black, Asian and Minority Ethnic (BAME) people in the film production workforce fell from 12\% in 2009 to 5.3\% in 2012 (Creative Skillset, 2013). As noted by Keith Randle, only $1 \%$ of visual effects workers in 2012 were BAME, compared to $9 \%$ of workers in all industries (Randle, 2015). In the same period, the proportion of the workforce reported by employers as disabled also fell from 1.9 to $1.5 \%$ (Creative Skillset, 2013). While by some measures gender representation in the film industry is roughly equal (47\% in 2012), analysis has shown that key, high-status creative roles tend to be male-dominated (Steele, 2013). Between 1999 and 2003, fewer than 15\% of UK films were credited to a female screenwriter (Sinclair, Pollard, \& Wolfe, 2006), and the most recent film credit analysis produced by the BFI (2014) shows that only $14 \%$ of directors and screenwriters were women in 2012/2013 (Fig. 2).

Fig. 2

Film production workforce participation of women, BAME and disabled people, 2009-2012. Source: Creative Skillset (2013, p. 31)

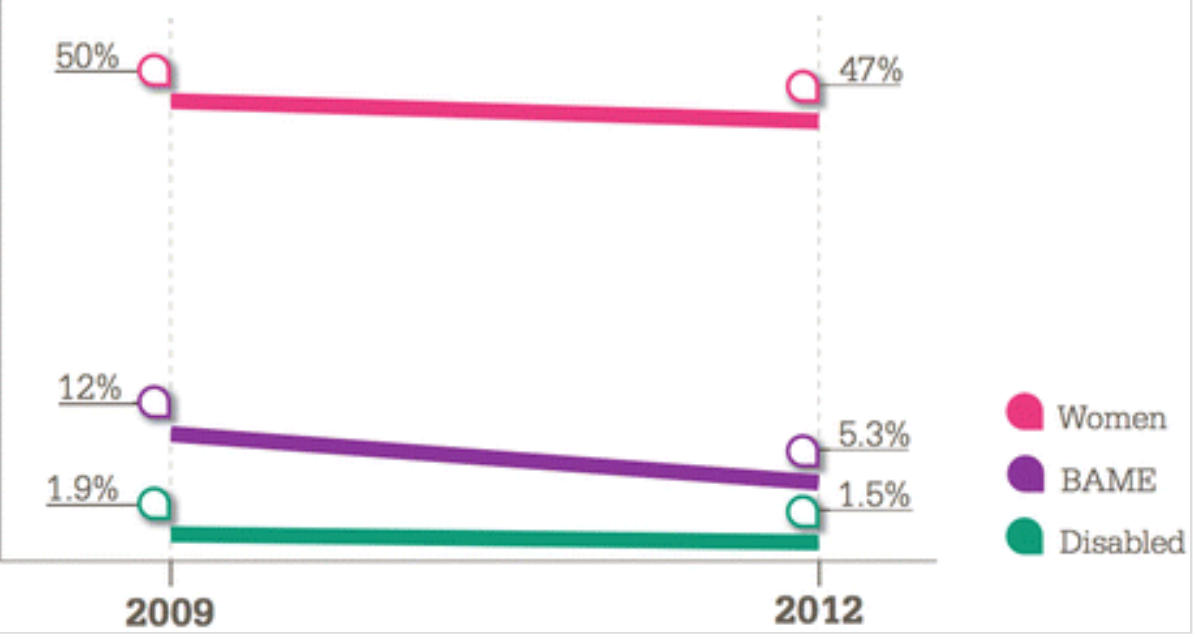


The persistent lack of diversity in the UK film industry workforce has been subject to considerable investigation and analysis which has identified a range of interlinked causal factors. In 2007, an investigation commissioned by the European Union's European Social Fund found "little tangible evidence of direct discrimination or overt prejudice against particular minorities" (Randle, Leung, \& Kurian, 2007, p. 9). Instead, it locates the barriers for marginalised social groups in the requirements of entry into and progression in film labour markets. Those seeking to enter the workforce are often expected to obtain an undergraduate degree and then work, often near London, for no or very low pay for a number of years which limits participation to those with significant financial resources and/or support. Given the disproportionate concentration of ethnic minorities in lower socio-economic categories, the lack of ethnic diversity in the workforce may be more to do with the structural intersection of race and class than with racial prejudice and discrimination (Randle et al., 2007, p. 10).

In a follow-up study on freelance women film and television workers, Leung, Rosalind Gill and Randle isolate two major factors limiting gender equality: "informality" and "parenting". They note that the "most distinctive feature of recruitment in the sector is its informal, word of mouth nature" (p. 56), with people being hired for short-term projects at short notice based on personal recommendations and previous working relationships. Networking is seen as "a time-consuming and demanding requirement of freelancing" (p. 57) which places additional burdens upon women. As personal trust is viewed by employers as vital, there is a tendency towards "homophily", "the practice of insiders recruiting in their own image, or selecting candidates with whom they feel they have an easy rapport" (p. 57). Given that most decision makers tend to be (white) men, this replicates existing gender inequalities. Parenting contributes to gendered inequality due to the "automatic connection between gender and childcare" drawn in the sector, "taking for granted the idea that parenting is primarily women's responsibility" (p. 59). Leung, Gill and Randle outline two factors that are sometimes conflated: a difficulty of balancing strenuous creative work with childcare for women who do have children and the assumption that childless younger women will choose to have children, causing employers to perceive them as less committed to work and invest fewer resources in them. Informality in recruitment processes makes proving discrimination very difficult, while short-term contracts and the importance of personal reputation mean workers are discouraged from complaining for fear of the damage this will do to their careers (Leung, Gill, \& Randle, 2015). As O'Brien (2014) argues, the "dependence on informal networks for work and promotion" mean that "the question of gender bias could not be tackled or addressed directly or formally" (p. 1216).

Research has also explored barriers to equal participation built into labour processes in the film industry. In the only empirical study to explore the experiences of disabled film and television workers, Randle (2015) notes a "double disablement" in access to film and television labour markets and in performing labour processes prevalent in the sector. The traditional entry level role as a "runner" "involves long hours, low pay and requires workers to respond quickly and to be highly mobile" (p. 12), all of which can inhibit people with impairments. Disabled workers are socially and culturally excluded from professional networks and may also be physically excluded from networking events which often take place in inaccessible social venues.

Although "few workers reported direct or overt forms of discrimination", Randle argues that "discrimination appeared to operate more insidiously" (p. 20).

In summary, participation in the film industry in the UK is highly unequal with persistent intersectional barriers structured into labour markets and labour processes that discriminate in terms of gender, ethnicity, disability and social class (Banks \& Hesmondhalgh, 2009, p. 420; Bhavnani, 2007). This is now well known. However, the extent to which this is a by-product of a system maintained through public funding has received far less scrutiny. Doris Eikhoff and Chris Warhurst have argued that social inequalities in employment are a direct result of the model of production in the creative industries. Short-term contracts, project-based work, informal recruitment practices and the associated disproportionate reliance on freelance labour are a response by employers to the inherent uncertainty as to what cultural products will be commercially successful, placing the risks of cultural production upon workers themselves. This means that any attempts to increase diversity that do not tackle the structure of the industry are likely to be unsuccessful. As Eikhoff and Warhurst argue, "a meritocratic world of work cannot be delivered within the creative industries' current model of production" (Eikhof \& Warhurst, 2013, p. 504).

The public policy response has, however, been slow and to date profoundly inadequate. For example, Mark Banks and David Hesmondhalgh identify 2007's Staying Ahead report as the first to identify problems in the 
lack of diversity in the creative industry workforce. As they note: "the report chooses not to elaborate on the causes and consequences of these social disparities. Nor does it suggest how labour markets might be progressively reformed in order to overcome these problems. Instead, the 'diversity' issue is elided, and, indeed, more substantively represented as a problem of individual rather than social origin" (Banks \& Hesmondhalgh, 2009, p. 423).

A good summary of the problem of diversity in New Labour film policy is made by Nwonka (2015). He notes that "the film industry continued to resist an interrogation of the hegemonic employment practices" despite mounting evidence that these played the fundamental role in reproducing inequality in the workforce. Instead, underrepresentation was understood as rooted in a lack of formal qualifications and training opportunities for ethnic minorities, the appropriate response being "a simplistic democratisation of previously unequal access to filmic education" (p. 12). He continues: "In this way, the UKFC's diversity agenda was energised by a continuing evasiveness and a plethora of paradoxical impulses of discriminatory recruitment cultures, which populate British film in an era of increasing inequality of opportunity" (p. 12). For Nwonka, "the very nature of diversity has, paradoxically, performed a key role in maintaining the status quo" (p. 13).

\section{The UK’s Corporate Welfare System: Maintaining Systemic Barriers}

The main argument of this chapter is that the dominant mode of film funding in the UK, which we have described as a corporate welfare model, maintains a structure and organisation of the film industry that directly mitigates against addressing the lack of workforce diversity. As we have shown, this model emerged in the 1990s and has continued apace since then and, while it has afforded a number of commercial benefits to the industry, has contributed to the polarisation of the production sector.

On the one hand, a small number of established companies make films with Hollywood finance attracted by the tax relief, high-end facilities and a highly skilled, flexible labour force, and on the other, a large number of small companies rely on under-resourced public funders to leverage patchwork finance for low- to medium-budget, culturally British films. The tax relief has cost the UK taxpayer an estimated $£ 1.45$ billion (1.72 billion euros) between 2006 and 2014, yet policymakers, broadcasters and funders have been unable to change discriminatory practices and cultures that characterise the industry. On the contrary, the structural conditions that produce this lack of diversity have been strengthened. As we have argued, these conditions represent barriers to participation that prevent selected disadvantaged groups in society from participating in film production.

The significance of this point is twofold: firstly, that initiatives designed to increase diversity are unlikely to be successful unless these underlying structures are addressed, and, secondly, that public funding for the film industry suffers through a contradiction that runs to the very heart of cultural-creative industries policy, the incompatibility of narrow corporate interests and wider sociocultural interests that emerge from civil society. It is notable that there is evidence to suggest that many of the negative conditions that exist in the film labour market and labour processes are mitigated, to some degree, within parts of the broadcast sector that have been shielded from the full force of commercialisation in the period under scrutiny, such as the $B B C$ and Channel 4 (see, e.g. Steele, 2013). While being progressively eroded, the production models and relatively high levels of unionisation in these organisations provide a more stable and accountable platform for the integration of social concerns within cultural production. If they are lost or significantly deregulated, as seems likely (Presence, 2017), this will further emphasise the trends described above towards fragmentation, precarity and inequality that pervade the UK film industry.

The "corporate welfare system" for film artificially increases the size and economic activity of the commercial UK film sector but does nothing to use this leverage to shape the labour market or labour process in favour of equality of participation. Consequently, the film industry benefits from substantial amounts of public money without the requirement to address the structural issues that prevent women, working class people, members of ethnic minorities and the disabled from participating in it. While this is a clear question of social and economic justice, it also speaks to a profoundly important question about the distribution of cultural and communicative resources. As Oakley rightly argues, "Who gets to make culture [...] matters, because it is how we understand ourselves as a society" (Oakley, 2013, p. 56). 
All of the features of the UK film labour market described in this chapter - the high economic and cultural capital required to gain entry, informal recruitment practices, "homophily", short-term contracts and job insecurity - are reflections of an industry where capital is strong and labour is weak. The pathological and systemic lack of diversity that characterises the UK film industry is a symptom and expression of the power of global media conglomerates to shape national and local labour markets in their own interests: highly skilled, highly flexible production units available for short-term hire. If this argument is correct, then it follows that any initiatives, policies or activities aimed at increasing workforce diversity to more equal levels are unlikely to have anything more than short-term superficial effects unless it is combined with systemic change that counterbalances the labour-capital power relationship more in favour of labour. The corporate welfare model of public film funding is uniquely and fundamentally incapable of achieving these aims.

\section{Acknowledgement}

Part of the research upon which this chapter is based was conducted in collaboration with Chris Larkin and William Green at the University Leicester for the Creative Industries, Diversity and Austerity (CIDA) Project. The chapter also draws on research conducted in collaboration with Andrew Spicer and Auden Engelstad for Success in the European Film and Television Industries (SiFTI), a comparative study of four European countries funded by the Norwegian Research Council (2013-2016).

\section{References}

AQ7

Arts Council England. (2011). The creative case for diversity. London: Arts Council England.

Banks, M., \& Hesmondhalgh, D. (2009). Looking for work in creative industries policy. International Journal of Cultural Policy, 15(4), 415-430.

Bhavnani, R. (2007). Barriers to diversity in film: A research review. London: UK Film Council.

British Film Institute. (2014). Statistical yearbook 2014. London: BFI.

British Film Institute. (2015a). Fihn and other sereen seetor prodtetion in 2014. BFI researeh and statisties. Eonden: BFI.

British Film Institute. (2015b). Public investment in UK film. BFI research and statisties. London: BFI.

British Film Institute. (2015e). Film industry empanies. BFI researeh and statisties. London: BFI.

British Film Institute. (2016a). Screen sector production in 2015. BFI research and statistics. London: BFI.

British Film Institute. (2016b). Public investment in film in the UK. BFI research and statistics. London: BFI.

British Film Institute. (2017). Summary of points - Cultural test for film. London: BFI.

http://www.bfi.org.uk/film-industry/british-certification-tax-relief/cultural-test-video-games/summary-pointscultural-test-film

Caterer, J. (2011). The people's pictures: National Lottery film funding and British Cinema. Newcastle upon Tyne: Cambridge Scholars Publishing.

Chakrabortty, A. (2014, October 6). Cut benefits? Yes, let’s start with our £85bn corporate welfare handout. Guardian.

Comunian, R., Faggian, A., \& Jewell, S. (2011). Winning and losing in the creative industries: An analysis of creative graduates' career opportunities across creative disciplines. Cultural Trends, 20(3-4), 291-308. 
Creative Industries Federation. (2016). Creative diversity: The state of diversity in the UK's creative industries and what we can do about it. London: Creative Industries Federation.

Creative Scotland. (2015). Equalities, diversity and inclusion report 2015.

Creative Skillset. (2013). Employment census of the creative media industries 2012.

DCMS - Department for Culture, Media and Sport. (2008). Creative Britain: New talents for the new economy. London: Department for Culture, Media and Sport.

Diekinson, M., \& Street, S. (1984). Cinema and state: The fint indtustry and the British government, 192784. Londen: BFI.

Eikhof, D. R., \& Warhurst, C. (2013). The promised land? Why social inequalities are systemic in the creative industries. Employee Relations, 35(5), 495-508.

Farnsworth, K. (2012). Social versus corporate welfare: Competing needs and interests within the welfare state. Basingstoke: Palgrave Macmillan.

Hesmondhalgh, D., Oakley, K., Lee, D., \& Nisbett, M. (2015a). Were New Labour's cultural policies neoliberal? International Journal of Cultural Policy, 21(1), 97-114.

Hesmondhalgh, D., Oakley, K., Lee, D., \& Nisbett, M. (2015b). Culture, economy and politics: The case of New Labour. London: Palgrave Macmillan.

Higson, A. (2011). Film England: Culturally English fltmmaking since the 1990s. London: I. B. Tauris.

Higson, A. (2015). British cinema, Europe and the global reach for audiences. In I. Bondebjerg, E. Redvall, \& A. Higson (Eds.), European cinema and television: Cultural policy and everyday life (pp. 127-150). Basingstoke: Palgrave Macmillan.

Hill, J. (1996). British film policy. In A. Moran (Ed.), Film policy: International, national and regional perspectives (pp. 101-113). London: Routledge.

Hill, J. (2012). This is for the Bamans as well as the Vera Drakes: Economies, eultmre and UK government film production poliey in the 2000s. Journal of British Cinema and Television, 9(3), 333-356.

Hill, J. (2016). Living with Hollywood: British film policy and the definition of 'nationality'. International Journal of Cultural Policy, 22(5), 706-723.

House of Lords Select Committee on Communications. (2010). The British film and television industries Decline or opportunity? The report (Vol. 1). London: The Stationary Office Limited.

Huff, D. D., \& Johnson, D. A. (1993). Phantom welfare: Public relief for corporate America. Social Work, $38(3), 311-316$.

Jäckel, A. (2003). European film industries. London: BFI.

Leung, W. F., Gill, R., \& Randle, K. (2015). Getting in, getting on, getting out? Women as career scramblers in the UK film and television industries. The Sociological Review, 63, 50-65. https://doi.org/10.1111/1467954X.12240

Nader, R. (2000). Cutting corporate welfare. New York: Seven Stories Press.

Newsinger, J. (2012a). British film policy in an age of austerity. Journal of British Cinema and Television, 
$9(1), 133-144$.

Newsinger, J. (2012b). The politics of regional audio-visual policy in England: Or, how we learnt to stop worrying and get "creative". International Journal of Cultural Policy, 18(1), 111-125.

Newsinger, J. (2014). A cultural shock doctrine? Austerity, the neoliberal state and the creative industries discourse. Media, Culture and Society, 37(2), 302-313.

Nwonka, C. (2015). Diversity pie: Rethinking social exclusion and diversity policy in the British film industry. Journal of Media Practice, 16(1), 73-90.

O'Brien, A. (2014). 'Men own television': Why women leave media work. Media, Culture \& Society, 36(8), 1207-1218.

Oakley, K. (2011). In its own image: New Labour and the cultural workforce. Cultural Trends, 20(3-4), 281289.

Oakley, K. (2013). Absentee workers: Representation and participation in the cultural industries. In M. Banks, R. Gill, \& S. Taylor (Eds.), Theorizing cultural work: Labour, continuity and change in the cultural and creative industries (pp. 56-67). London: Routledge.

Olsberg SPI. (2015). The economic contribution of the UK's film, high-end TV, video game, and animation sectors. A Report Presented to the BFI, Pinewood Shepperton plc, Ukie, the British Film Commission and Pact by Olsberg SPI with Nordicity.

Presence, S. (2017, forthcoming). The finance and production of independent film and television in the UK: A critical introduction. In E. Bakøy, R. Puijk, \& A. Spicer (Eds.), Building successful and sustainable film and television businesses: A cross-national perspective. Bristol: Intellect.

Randle, K. (2015). Class and exclusion at work: The case of UK film and television. In K. Oakley \& J. O'Connor (Eds.), The Routledge companion to the cultural industries (pp. 330-343). London: Routledge.

Randle, K., \& Hardy, K. (2015). Macho, mobile and resilient? How freelance workers with impairments are doubly disabled in project based film and television work. Work, Emploment and Society, 1-18. https://doi.org/10.1177/0950017016643482

Randle, K., Leung, W.-F., \& Kurian, J. (2007). Creating difference: Overcoming barriers to diversity in UK film and television employment (pp. 1-172). Hertfordshire: Creative Industries Research \& Consultancy Unit.

Sinclair, A., Pollard, E., \& Wolfe, H. (2006). Scoping study into the lack of women screenwriters in the UK: A report presented to the UK Film Council (pp. 1-124). Brighton: Institute of Employment Studies for the UK Film Council.

Steele, D. (2013). Succès de plume? Female screenwriters and directors of UK films, 2010-2012 (pp. 1-15). London: British Film Institute.

Steele, D. (2015). Rethinking the focus on UK film support: Is subsidising US Studios a safe strategy for UK film production in the coming decade? International Journal of Cultural Policy, 24(1), 74-79.

Treasury Press Release, HM. (2015, August 21). Chancellor: We're backing British film industry. London: HM Treasury. https://www.gov.uk/government/news/chancellor-were-backing-british-film-industry

UK Film Council. (2010). Statistical yearbook 2010. London: UK Film Council.

Whitfield, D. (2001). Public services or corporate welfare: Rethinking the nation state in the global economy. 
The concept of a "corporate welfare system" is most heavily associated with Kevin Farnsworth's (2012) research on "business subsidy", which sparked a public debate in 2015 after being picked up for investigation by the centre-left Guardian newspaper (Chakrabortty, 2014).

It should be noted, however, that in Hesmondhalgh et al.'s account (2015b, pp. 104-108), film policy under New Labour is characterised as more straightforwardly commercial. 3

The UK withdrew its membership from Eurimages despite it generating an estimated $£ 40$ million (47 million euros) in film activity in return for the $£ 5.5$ million (6.5 million euros) membership fee, a decision which reflects the extent to which UK film policy was, and remains, highly Eurosceptic and geared towards attracting inward investment from the USA (Higson, 2015, p. 130; Jäckel, 2003, p. 79). 4

The UK currently has 12 bilateral agreements with other countries: Australia, Brazil, Canada, China, France, India, Israel, Jamaica, Morocco, New Zealand, occupied Palestinian territories and South Africa. The UK has also ratified the European Convention on Cinematographic Co-production, and films accorded co-production status under this agreement also qualify for tax relief. Created in 1992, the convention aims to encourage European co-production by allowing three or more companies from different European countries to benefit from tax relief on a single production. Like everything else since Brexit, what will happen to this convention after Article 50 is invoked is unclear.

Categorised by the BFI as domestic UK features, the median budget of these films was just $£ 430,000$ (600,000 euros). It should also be noted that the median budget for UK independent films is likely to be revised even lower because of the delay in acquiring data about low- and micro-budget productions (BFI, 2016a, pp. 2-8). 